\title{
Morphological Knowledge for the Modeling of Ottoman Mosques
}

\author{
Najla Allani-Bouhoula \\ National School of Architecture and Urbanism, University of Carthage, Tunisia \\ *Corresponding Author: Najla.allani@enau.rnu.tn
}

Copyright (C) 2014 Horizon Research Publishing All rights reserved.

\begin{abstract}
The Ottoman mosque can be considered as one of the three main families of architectural forms characterizing the Muslim mosque. In this paper, we present the preliminary results of our work on computer modeling of the Ottoman mosques built by Sinan in the 16th century. We started first by conducting an analysis of a corpus of 26 mosques. We have developed a tool called "SINAN" through which various possible queries are allowed to understand the characteristics of these mosques and the laws that govern them. This is a database exploitable through a data interface. Second, and in order to build a knowledge base for the semi-automatic modeling of Ottoman mosques, we started by specifying rules related to Ottoman mosques using Horn clauses then we used the decision procedures, to verify the consistency of the rule base.
\end{abstract}

Keywords Modeling, Morphological Analysis, Architectural Knowledge Base, Decision Procedures, Othman Mosques

\section{Introduction}

Restitution of historical monuments to simulate, study or even restore, has always led the architects and archaeologists to develop small models, which was always considered as a painful task and expensive. Modeling architecture has evolved considerably, especially with the development of tools and new techniques through the computer. But most digital tools used for architectural modeling heritage are based on architectural survey tools such as photogrammetry $[1,2]$ or acquisition laser $[3,4]$. Although these tools offer a high degree of automation and precision increasingly important, their reconstruction procedures are limited to a geometric interpolation of metric data that are far from being in accordance with the objectives of representation adapted to the architects working mode and which do not use the architectural knowledge regarding to the historical period of the considered building.

During the last years, we have seen the emergence of a number of works in the field of architecture with an interest in architectural modeling [5, 6, 7, 8, 9 and10]. These researches try to achieve the development of modeling tools which are more suitable to architects work methods. This paper falls within this stream with a focus on the modeling of Ottoman mosques.

Ottoman architecture is considered as an expression of the renaissance of Islamic architecture. The Ottoman mosques and especially those built after the conquest of Constantinople are witnesses of the emergence of the central dome as a structuring element of their spaces. This new form of mosque architecture reached its peak in the 16th century with Sinan, the chief architect of the empire at that time [11]. The Ottoman mosque is known as one of three main architectural forms characterizing the Muslim mosque. Its specific spatial structure has continued to attract the growing interest of researchers in various fields and has continued to be a source of inspiration for architects.

This paper is the result of a research project launched during the supervision of a Master project [12] and finalized during the preparation of my habilitation research degree [13].

In this paper, we propose a semi-automatic technique to generate ottoman mosques models through the design of an architectural knowledge base, the use of decision procedures for the consistency checking of the knowledge base and the use of decision procedures to minimize the interaction with the user. To do this, we have to collect a corpus of 26 domed Ottoman mosques designed by Mimar Sinan in the 16th century.

\section{Presentation of the Object of Study}

\subsection{Definition of the Mosque}

A mosque is a place of worship where Muslims gather for communal prayers. The name "Masjid" means "put the forehead to the ground" and reminds that it is a place of prostration. The term "Jamaa" (meeting place), refers to a mosque where takes place the meeting on Friday. Friday 
prayer is characterized by the khutbah (speech of Imam). That day all the Muslims, other days, stuck to their local mosques, gathered in the main mosque led by the Imam.

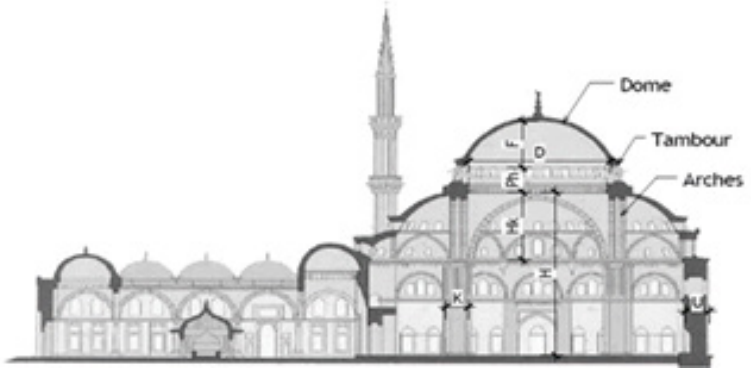

Figure 1. Different entities of ottoman mosque

\subsection{Main Families of Mosques}

- Hypostyle Mosques: The plan called "Arab" or "hypostyle" It is based on a model more or less mythical: the house of the Prophet in Medina. The Arab plan or hypostyle plan is a plan in square or rectangular shape that consists of a portico courtyard and a prayer room with columns, the naves being directed parallel or perpendicular (for the Maghreb and some exceptions) to the qibla. It is found throughout the Islamic world, from Syria to North Africa, Spain and Iraq. Mosques Arab plan were built especially under the reign of the Abbasids and Umayyads.

- Iranian Plan: As its name suggests, this plan is found almost exclusively in Greater Iran, that is to say, in a region including Iran, part of Afghanistan and Pakistan and parts of Iraq. It was also the design used in India before the Mughal dynasty. It appears in the tenth century with the Seljuk dynasty and is characterized by the use of iwans a pishtak and a prayer room under dome. Generally, over the mosques have four arranged in a cross. A pishtak is forming an advanced, often topped by two minarets and opened by a large arch gate. The Shah Mosque in Isfahan is one the best examples known of Iranian Plan.

- Ottoman Plan: This plan is mainly in Turkey, and was developed after the fall of Constantinople in 1453 by the architect Sinan, the greatest builder of Turkish mosques that are assigned more than 300 buildings, including the Süleymaniye Mosque at Istanbul. However, we find the beginnings since the thirteenth century in the first Ottoman art. It consists of a prayer room in a huge dome confined half-domes and couplettes. There are also in addition to the central dome are often smaller domes in the rest of the mosque, even where prayer is not performed. Often, Ottoman mosques are part of large complexes. One can detect a Byzantine influence (of Hagia Sophia in particular) $[14,15,16,17,18$, and 19].

\subsection{Essential Components of the Mosque}

- The prayer hall: it is essentially a covered area with a main dome and sometimes additional elements that ensure its structural stability.

- The Covered playground: is a transition space between the exterior and the interior. It is composed of one or two galleries. It is characterized by the number of domes that cover it and the number of arches in its facade.

- The Court: It is a patio open pit often juxtaposed to the prayer room. It allows to extend the area of prayer. It is a specific component of the imperial mosques.

- Minarets: are towers used to call the faithful to prayer by a muezzin. The Minaret is an aesthetic element in Ottoman mosque. Its impact on the silhouette of the mosque and its sleek appearance illustrate the link between sacred and profane.

- The mihrab: The niche marking the Qibla (direction of Mecca)

\section{Morphological Analysis}

In the first stage of our work, we performed a morphological analysis in accordance with the method of Professor Duprat [20] to determine the rules governing and concerning the specific morphological, dimensional and geometrical aspects of each family of objects.

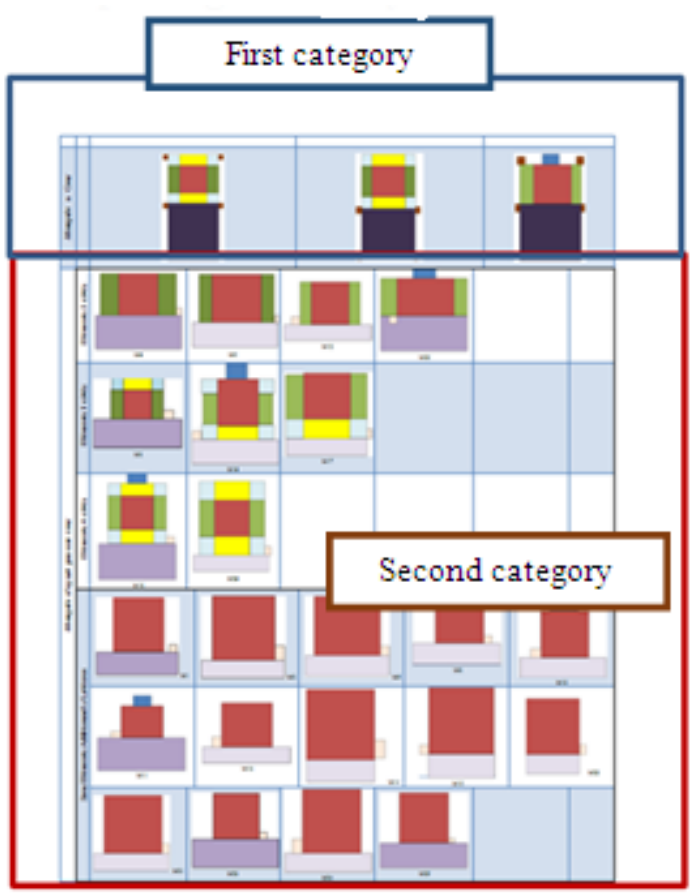

Figure 2. Table of homology of the various entities of the corpus

We decompose the purpose of the study in different intelligible spatial entities to mark morphological discontinuities and identify different alternatives. Then, a work of reconstruction can make visible the various 
interrelations between the components of the studied object.

The decomposition of the corpus allowed us to distinguish four intelligible morphological entities of the mosque which are: the prayer hall, the access devices (covered playgrounds, court) and the minarets (see figure 2)

\subsection{The Prayer Hall}

The prayer hall is a covered space devoted to prayer. It is composed primarily of a main dome and sometimes additional elements that ensure its structural stability. The main dome is the essential element of an Ottoman mosque. The system that supports the dome is a characteristic feature of the dome. Güngör [11] distinguished three types of support systems in Sinan work: the square, the hexagonal and the octagonal system (see figure 3). Sinan treats the dome as the most important spatial element. So he created different spaces and positioned the dome relationship with the general mass of the structure. Assuming that the center of the dome is positioned in an orthogonal axis with two perpendicular axes ( $\mathrm{X}$ horizontal and $\mathrm{Y}$ vertical) several positions are resulting (see figure 4).

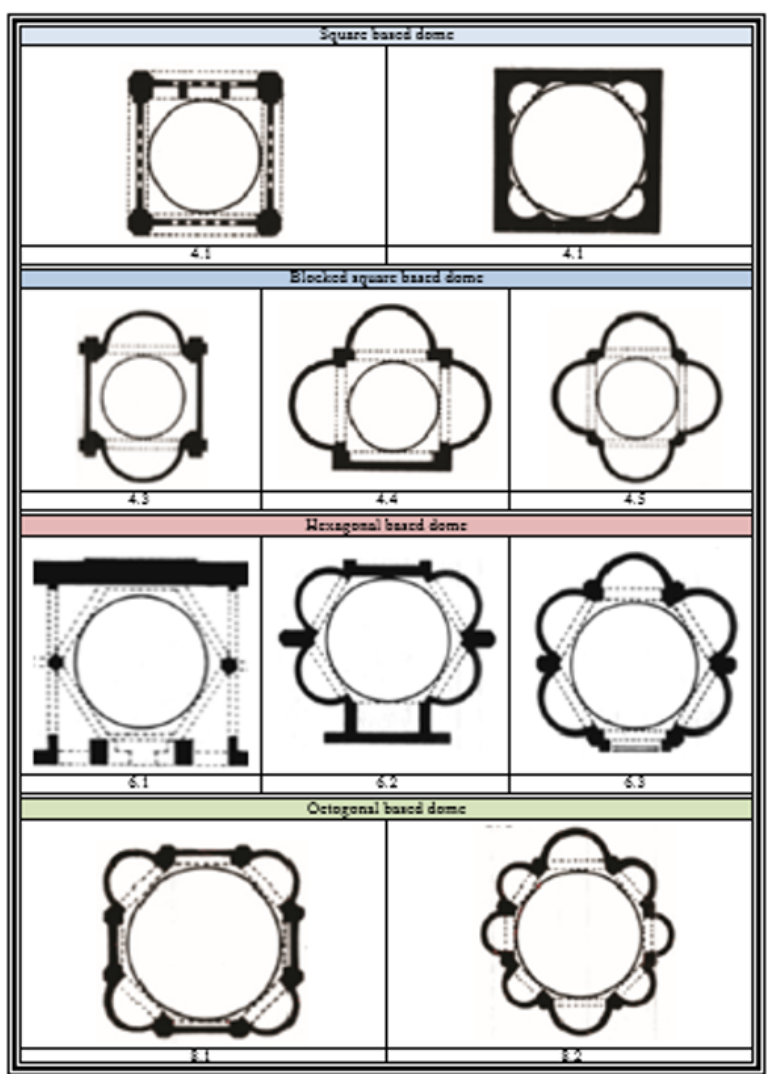

Figure 3. Domes support systems

$\mathrm{X}$ indicates the direction in which the dome is translated: If $X=1$ then the dome is centered,

If $X=2$ then the dome is translated in the direction of the Qibla.

If $X=3$ then the dome is translated to the front wall.

The second variable refers to the presence or absence of lateral spaces at the periphery of the dome:

If $\mathrm{Y}=1$ : there is no addition.

If $Y=2:$ there are side additions

If $\mathrm{Y}=3$ : there are additions to the four directions of the dome.

The third variable refers to the presence or absence of a Mihrab, if $Z=1$ then there is no mihrab and if $Z=2$ then we have a mihrab.

The variation in the position of the dome creates the need to use additional elements to cover the resulting additional space. These elements can be (see figure 5 and figure 6):

- Semi-domes with square or hexagonal bases that support the main dome.

- Assemblages of two or three domes of the same dimensions or oversized for the medium dome or a flat roof.

- A single sloped roof.

- Corner domes if currently both longitudinal and lateral extensions.

- A flat roof

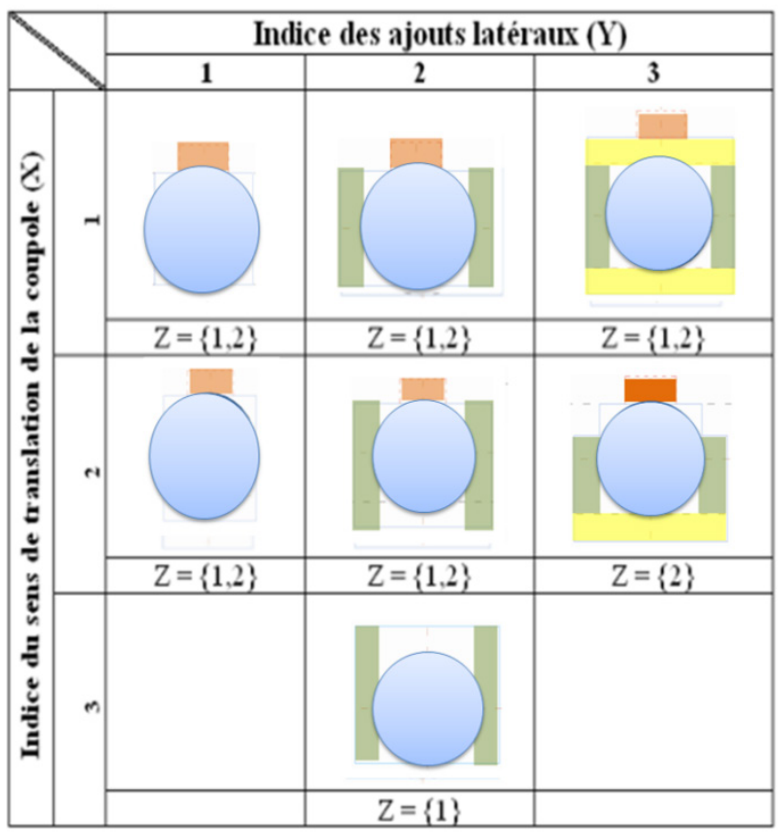

Figure 4. Possible structural patterns for an Ottoman domed mosque

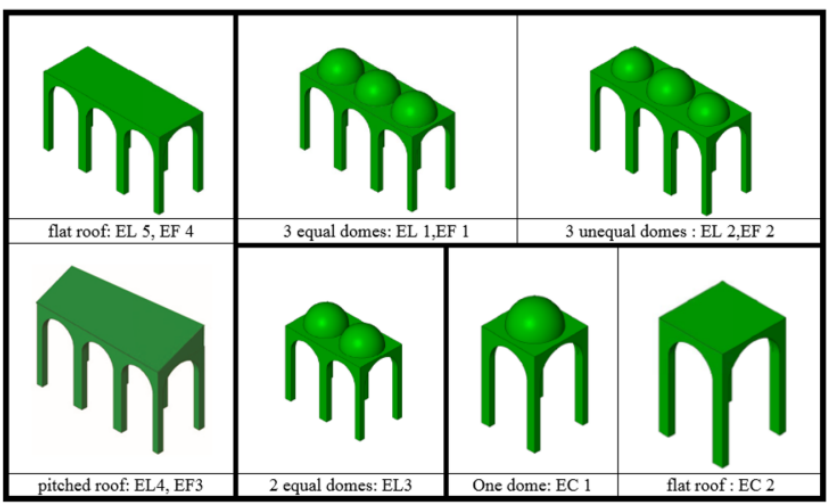

Figure 5. Different types of additional elements in the prayer hall 


\begin{tabular}{|l|l|l|}
\cline { 2 - 2 } \multicolumn{1}{c|}{} & Mihrab & \multicolumn{1}{c}{} \\
\hline EC & & EC \\
\hline EL & Dome & EL \\
\hline EC & EF & EC \\
\hline
\end{tabular}

Figure 6. The location of additional elements related to the dome

\subsection{The Access Devices}

The access devices of ottoman mosques can be divided into 3 types (figure 7):

A. The court

B. The covered playground with one gallery.

C. The covered playground with two galleries.

We define the parameters for these devices as follows:

- $\mathrm{S}_{1}$ number of arcades in the main covered playground

- $\mathrm{S}_{2}$ number of arcades in the covered playground side

- $\mathrm{S}_{\mathrm{f}}$ : number of arches of the courtyard facade

- $\mathrm{S}_{\mathrm{I}}$ : number of lateral arches of the courtyard

- $\mathrm{L}_{\mathrm{p} 1}$ : main covered playground Length

- $1_{\mathrm{P} 1}$ : width Awning main

- $\mathrm{L}_{\mathrm{p} 2}$ : Awning Length secondary

- $1_{\mathrm{p} 2}$ : Awning width secondary

- $\mathrm{L}_{\mathrm{c}}$ : Length of the court

- $1_{c}$ : width of the court

- $1_{g}$ : width of the gallery
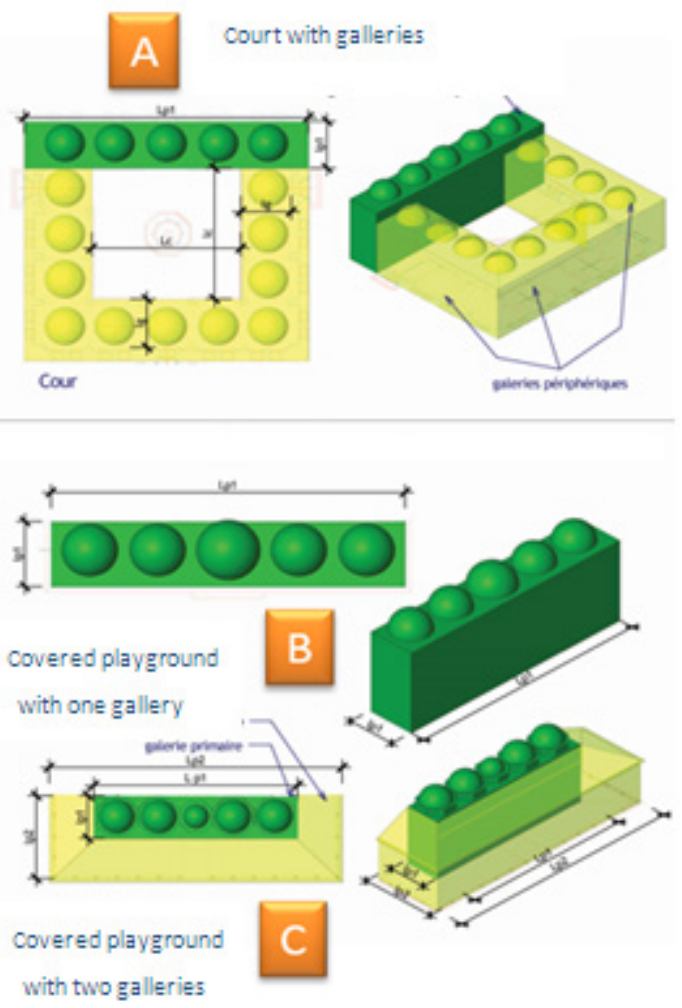

Figure 7. Access devices (Covered playground, court)

\subsection{The Minarets}

Minarets in ottoman mosques are composed of one, two or three balconies. In general, a mosque has a single minaret. Only imperial mosque has several minarets.

The parameters related to minarets are:

$\mathrm{N}_{\mathrm{m}}$ : Number of Minarets

$\mathrm{H}_{\mathrm{mp}}$ : Height of main minaret

$\mathrm{H}_{\mathrm{ms}}$ : Height secondary minaret

$\mathrm{N}_{\mathrm{bp}}$ : Number of balconies of main minarets

$\mathrm{N}_{\mathrm{b}}$ : Number of balconies secondary minarets

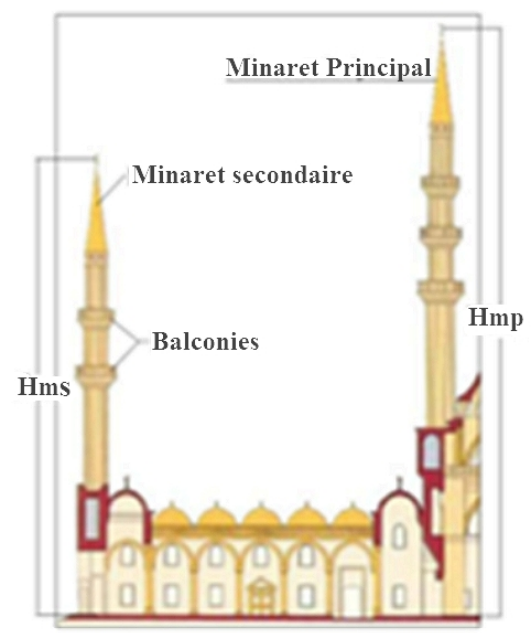

Figure 8. Minarets

Figure 2 shows the array of homology that we have established. This table allowed us to compare the result of the breakdown of the various mosques of our corpus.

This analysis allowed us to identify two main categories of mosques:

a. The first category has a court, it concerns samples M4, M7 and M15. These mosques have other common points which are:

- A dome diameter greater than $18 \mathrm{~m}$

- The area of the prayer space, which is more than $800 \mathrm{~m}^{2}$

- $\quad$ The number of minaret which is 2 or 4

- The status of the sponsor (Sultan)

b. The second category of mosques has no court can also be divided into two classes:

- The first class collects specimens M3, M6, M9, M12, M16, M17, M18, M20 and M26; and have the following in common:

- An area of the prayer space more than $250 \mathrm{~m}^{2}$

- A dome diameter greater than $12 \mathrm{~m}$

- The status of the sponsor (princes or viziers)

- The second class collects specimens M1, M2, M5, M8, M10, M11, M13, M14, M19, M20, M21, M23, M24 and M25. They are characterized by:

An area of the prayer space less than $200 \mathrm{~m}^{2}$

- A dome diameter less than $12 \mathrm{~m}$

- The status of the Sponsor (general or rich merchant)

According to Yerasimos [21], the status and the function of the sponsor is a determining factor in the definition of the 
class of mosque and its architectural components. It defines that there were three types of mosques namely small mosques, viziral mosques and imperial mosques.

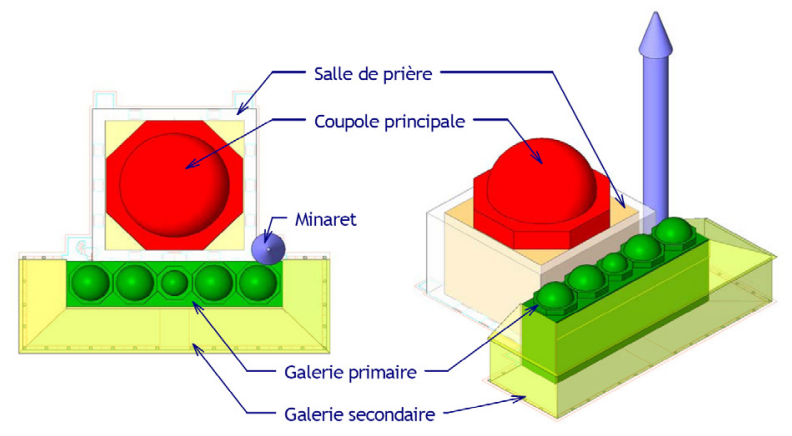

Figure 9. The components of a mosque in class 1

Morphological analysis that we carried out confirms the existence of three types of models that fit the classification of Yerasimos. These three categories of Ottoman mosques are:

- Mosques commanded by general or rich merchants are mosques without court where the prayer space does not have side and façade elements (see Figure 9)

- Mosques commanded by notable, viziers or princes are mosques without court where the prayer space has side and façade elements (see Figure 10)

- Finally mosques commanded by sultans are mosques with Court (see Figure 11).

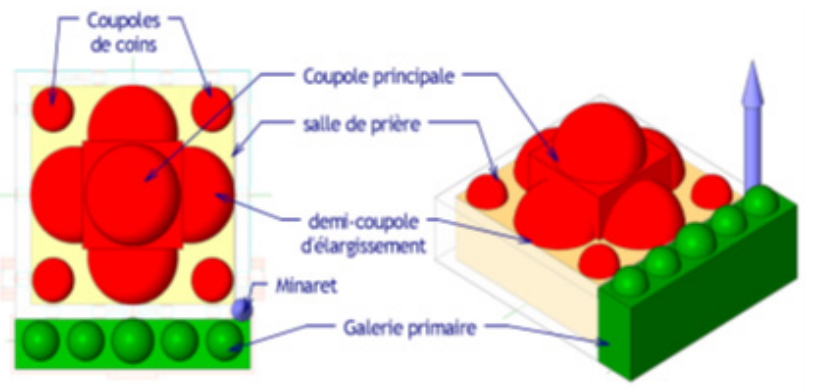

Figure 10. The components of a mosque in class 2 (Viziral)

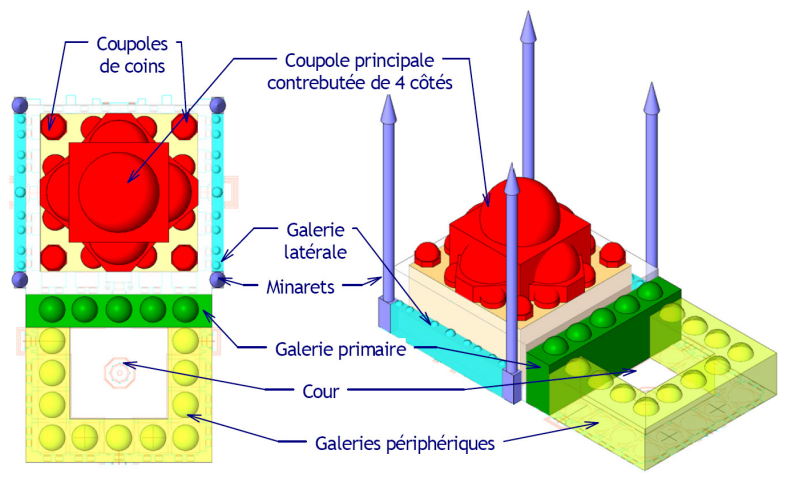

Figure 11. The components of a mosque in class 3 (Imperial)

At the end of the analysis, we proceeded to the interpretation of data and parameterization necessary for the modeling phase. Due to the significant number of parameters that we have to handle, our idea is to capitalize on the information collected during the analysis and combine them into a usable database through an interactive interface that responds to multiple and targeted requests to identify coherently modeling rules of Ottoman mosques.

\section{The "SINAN" Prototype}

We have created a database that includes all the values of the parameters used to model the studied Ottoman mosques (see Figure 10). This work has helped us to develop a prototype called "SINAN" (see Figure 11). This prototype allows us to offer two main modes:

1. Editing Data Mode: This mode allows you to view and update (modify, add and delete) information on mosques (see Figure 12)

2. Data query mode: This mode allows you to view all the details of the mosques from a single query or multiple queries given by the user.

"SINAN" is carried out using the programming language C \# net on the development environment Visual Studio 2010 Beta 2 and the .NET 4.0 platform. The software stores the data in a database and MS Access 2007 database access is done using optimized SQL queries to ensure the performance of the tool by rapid data access. In fact, optimization is achieved through the method of storing images in the database. "SINAN" stores the names of the images to use as a search index. Access to these images is done in an intuitive way by making a correspondence between the names and folders that contain images.

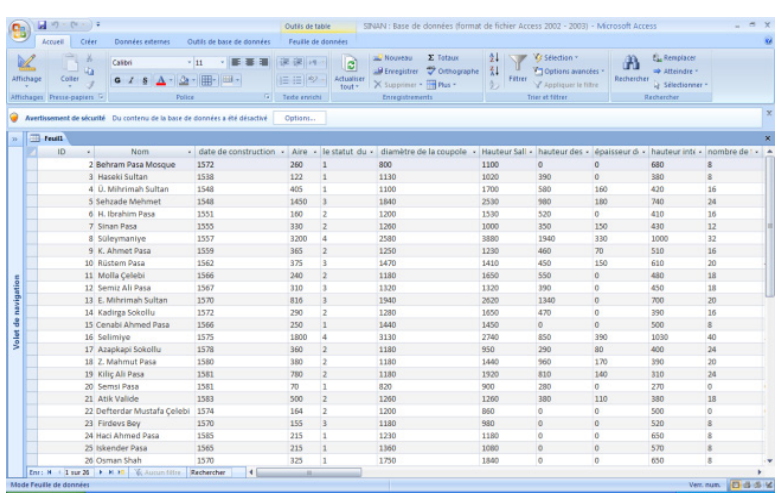

Figure 12. Database of Ottoman mosques

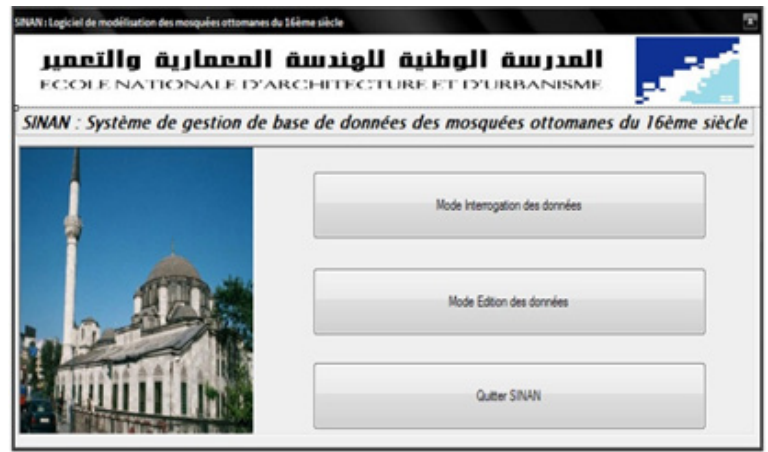

Figure 13. Main Menu prototype "SINAN" 


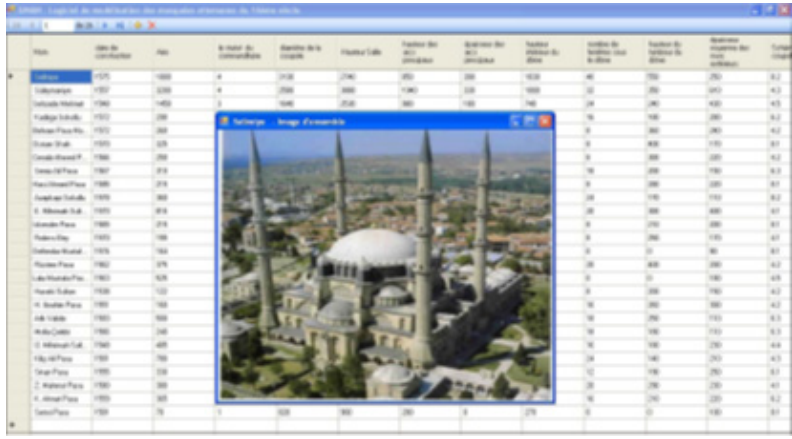

Figure 14. Consultation and update the data base

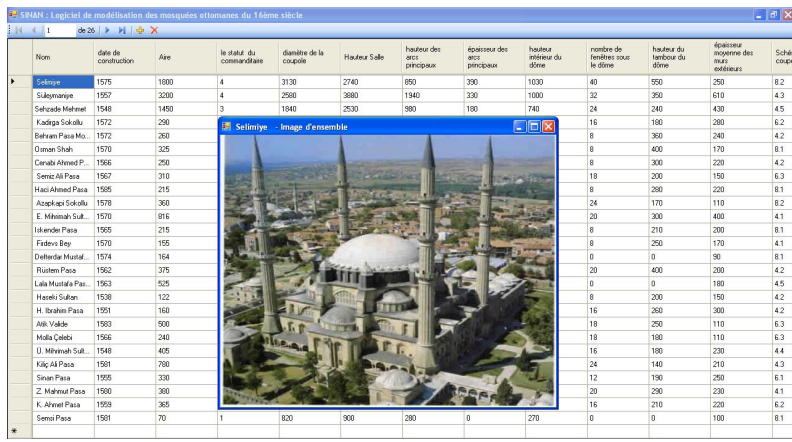

Figure 15. Consultation and update the database

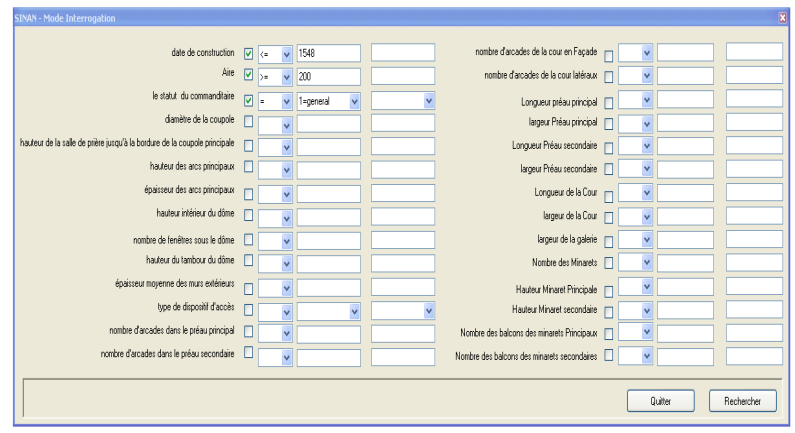

Figure 16. Introduction of the user query

Example of multiple queries with "SINAN" View all studied Ottoman mosques whose construction date is less than or equal to 1548 , the surface is greater than or equal to $200 \mathrm{~m} 2$ and the status of the sponsor is "general", see Figure 16. The answer to this query is given in Figure 17.

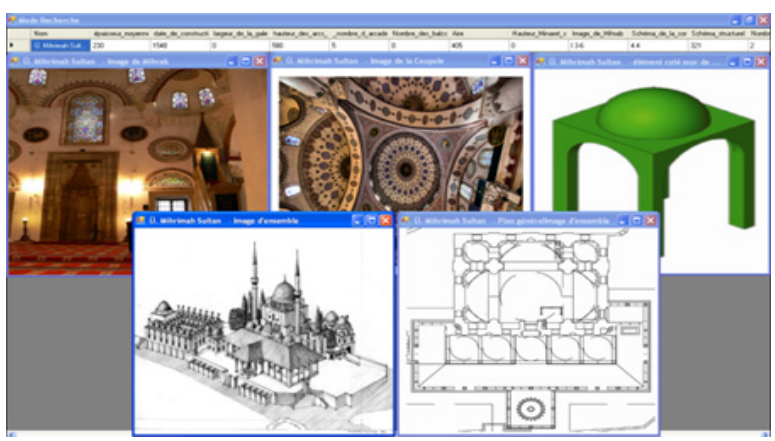

Figure 17. Display of the result of the user query

As we mentioned in the previous paragraph, this database allows us to identify coherently modeling rules of Ottoman mosques. It can also be used in the context of education. Indeed, "learning-by-doing" is a fundamental pedagogical approach in institutional education of architecture. But a number of academic courses including in particular courses of history of architecture is limited in most cases to a theoretical description, through projections, of the evolution of architectural forms. We can also note that in the work of architects, the notion of reference is important in the design process forms. Teaching this concept is not just limited to lectures. It is also addressed in the design exercises in the workshops of architecture in different levels including the 2nd and 4th year in study trips. Students are required after impregnation onsite of the specific architectural components in a particular context to present their own conceptual approaches in relation to a given project. Using a computer as a tool in heritage education could enhance the pedagogical approach of "learning-by-doing".

This database can therefore be used as an interactive tool for manipulating data on Ottoman mosques by students to discover their main components and characteristics. Then at a later stage we can develop a tool for teaching while taking advantage of knowledge acquired through artificial intelligence in this field. Students can use computers not only as a tool of representation, but also as a partner in education and design.

\section{Rule Base}

To build the knowledge base, we started first by specifying rules related to Ottoman mosques using Horn clauses. A Horn clause is a mathematical formula of the form:

condition $_{1} \wedge$ condition $_{2} \wedge \ldots \wedge$ condition $_{\mathrm{n}} \Rightarrow$ conclusion (1) where condition1, condition $2, \ldots$, condition $\mathrm{n}$ and conclusions are constructed from:

$>$ constants and variables (belonging to the set of real numbers),

$>$ addition + , multiplication *

$>$ equality or inequality predicates: $=, \neq,<,>, \leq, \geq$

\subsection{Rules Related to Central Dome}

We begin with the rules for the central dome where we have three rules. Rule $n^{\circ} 1$ states that if the shape of the dome of the mosque belongs to the set (I), the position of the dome belongs to the set (II) (see Figure 18) and the diameter of the dome is greater than $18 \mathrm{~m}$ then the type of the dome of the mosque is imperial.

Rule $n^{\circ} 1$

if form(dome, mosque)

$\in\{(3),(5),(9),(10)\} \wedge$

Position (dome, mosque)

$\in\{(\mathrm{d}),(\mathrm{f}),(\mathrm{g})\} \wedge$

diameter(dome, mosque) $>18 \mathrm{~m}$ then

type(dome, mosque) $=$ imperial 

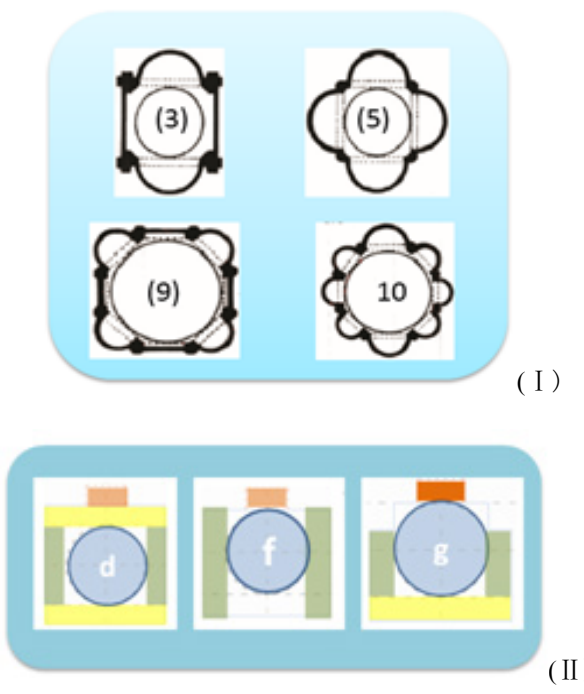

Figure 18. Form and position of central dome in the Imperial type

Rule $\mathrm{n}^{\circ} 2$ states that if the shape of the dome of the mosque belongs to the set (I), the position of the dome belongs to the set (II) (see Figure 19) and the diameter of the dome is greater than $12 \mathrm{~m}$ and less than $18 \mathrm{~m}$ then the type of the dome of the mosque is viziral.

\section{Rule $n^{\circ} 2$}

if form (dome, mosque)

$$
\in\{(1),(3),(5),(7),(10)\} \wedge
$$

Position (dome, mosque)

$\in[(\mathrm{a}) . .(\mathrm{h})] \wedge$

$12 \mathrm{~m}<$ diameter(dome, mosque $)<18 \mathrm{~m}$

$$
\begin{aligned}
& \text { then } \\
& \text { type(dom } \\
& \text { e, mosque)= } \\
& \text { viziral }
\end{aligned}
$$

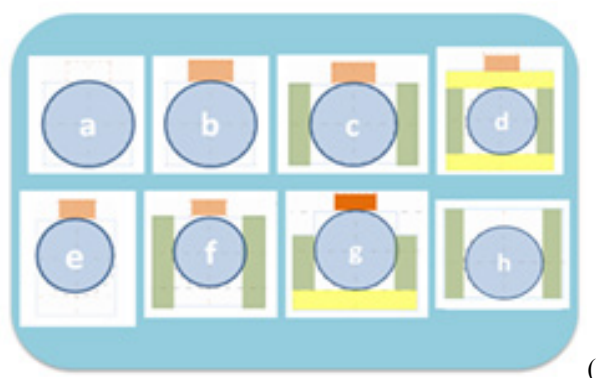

(II)

Figure 19. Form and position of central dome in the Viziral type

Rule $\mathrm{n}^{\circ} 3$ states that if the shape of the dome of the mosque belongs to the set (I), the position of the dome belongs to the set (II) (see Figure 20) and the diameter of the dome is less than $12 \mathrm{~m}$ then the type of the dome of the mosque is Small.

\section{Rule $n^{\circ} 3$}

$\begin{array}{lc}\text { if form }(\text { dome, mosque) } & \text { then } \\ \in\{(1),(2),(6),(9)\} \wedge & \text { type }(\text { dome, } \\ \text { Position }(\text { dome }, \text { mosque) } & \text { mosque })= \\ \in\{(\text { a }),(b)\} \wedge & \text { small } \\ \text { diameter(dome, mosque })<12 \mathrm{~m} & \end{array}$
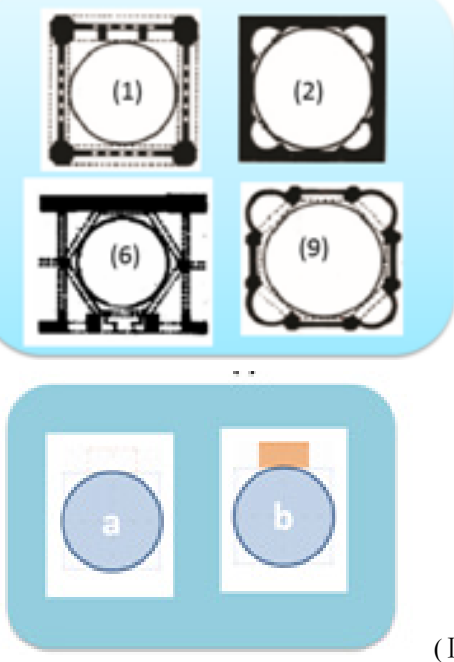

(II)

Figure 20. Form and position of central dome in the Small type

\subsection{Rules Related to Prayer Hall}

The rules related to prayer hall stipulate:

In a first case if the additional elements of the mosque are included in the set of figure 4 , the surface of the prayer hall is more than $800 \mathrm{~m} 2$, the access device to the prayer hall belongs to A (see figure 6) then the type of the prayer hall is imperial

Rule $n^{\circ} 4$

if add_elts (prayer_hall, mosque $\subseteq\{$ EL,EF,EC $\} \wedge$ surface (prayer_hall, mosque) $>800 \mathrm{~m}^{2} \wedge$ access_device(prayer_hall, mosque $) \in\{A\}$

\section{then type(prayer_hal 1$, mosque $)=$ imperial}

In a second case if the additional elements of the mosque are included in the set of figure 4 , the surface of the prayer hall is less than $800 \mathrm{~m}^{2}$, the access device to the prayer hall in $\{B, C\}$ (see figure 6), then the type of the prayer hall of the mosque is viziral.

Rule $n^{\circ} 5$

if add_elts (prayer_hall, mosque $) \subseteq\{\mathrm{EL}, \mathrm{EF}, \overline{\mathrm{EC}}\} \wedge$ surface (prayer_hall, mosque) $<800 \mathrm{~m}^{2} \wedge$ access device (prayer_hall, mosque) $\in$

then type(prayer_hall,mo sque $)=$ viziral $\{\mathrm{B}, \mathrm{C}\}$

In a third case if the additional elements of the mosque equal the empty set, the surface of the prayer hall is less than $200 \mathrm{~m}^{2}$, the access device to the prayer hall in $\{B$, 
C \} (see figure 6), then the type of the prayer hall of the mosque is Small.

Rule $n^{\circ} 6$

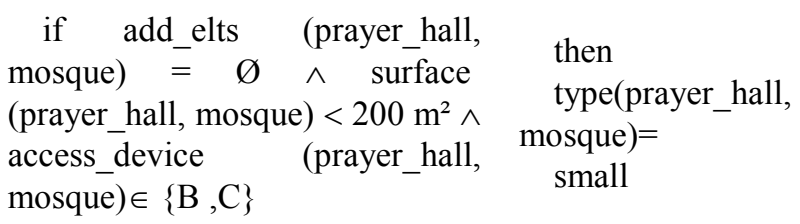

\subsection{Rules Related to Minarets}

We also specified the rules on minarets

Rule $n^{\circ} 7$

if nbre (minarets (a) mosque) $=1 \quad \begin{aligned} & \text { then } \\ & \text { type(minaret, } \\ & \text { mosque })=\text { small }\end{aligned}$

Rule $n^{\circ} 8$

if nbre (minarets (a) mosque) $=1$

then

type(minaret, mosque $)=$ viziral

Rule $n^{\circ} 9$

$\begin{array}{cl}\text { if nbre (minarets (b) mosque) }=2 & \begin{array}{l}\text { then } \\ \text { type (minaret, } \\ \text { mosque })=\text { imperial }\end{array}\end{array}$

Rule $n^{\circ} 10$

if nbre (minarets (c) mosque) $=$ 4

$$
\begin{aligned}
& \text { then } \\
& \text { type(minaret, } \\
& \text { mosque) = imperial }
\end{aligned}
$$

Rule $n^{\circ} 11$

if nbre (minarets (b) mosque) $=2$ $\wedge$ nbre $($ minarets $(\mathrm{c})$ mosque $)=2$

$$
\begin{aligned}
& \text { then } \\
& \text { type(minaret, } \\
& \text { mosque) = imperial }
\end{aligned}
$$

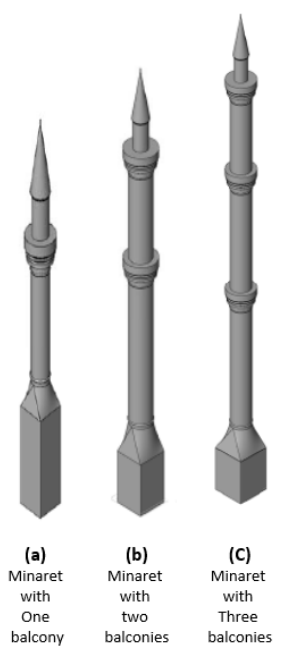

Figure 21. Different types of minarets
It should be noted that "nbre (minarets, $\mathrm{x}, \mathrm{m}$ ) $=\mathrm{n}$ 'is an atomic formula that translates the phrase" the number of minarets type $x$ in the mosque $m=n$ "where $x \in\{(a),(b)$, (c) $\}$ (see figure 21).

\subsection{Rules Identifying Mosques}

Now by using the rules that we defined earlier we can further specify rules allowing us to identify the type of the mosque

The rule $n^{\circ} 12$ allows us to deduce that if the type of the dome of the mosque is imperial, the type of the prayer hall of the mosque is imperial, the type of the minaret of the mosque is imperial then the type of the mosque is imperial

Rule $\mathrm{n}^{\circ} 12$

if type $($ dome, mosque $)=$ imperial $\wedge$

then type $($ prayer_hall, mosque $)=$ imperial $\wedge \quad$ type $($ mosque type $($ minaret, mosque $)=$ imperial $\quad$ ) imperial

The rule $\mathrm{n}^{\circ} 13$, allows us to deduce that if the type of the dome of the mosque is viziral, the type of the prayer hall of the mosque is viziral, type the minaret of the mosque is viziral then the type of the mosque is viziral.

Rule $n^{\circ} 13$

if type $($ dome, mosque $)=$ viziral $\wedge$ type $($ prayer_hall, mosque $)=$ viziral $\wedge \quad$ type $($ mosque $)=$ type $($ minaret, mosque $)=$ viziral viziral

Finally, regarding to the rule $n^{\circ} 14$, we can deduce that if the type of the dome of the mosque is small, the type of the prayer hall of the mosque is small, the type of the minaret of the mosque is small then the type of the mosque is small

Rule $n^{\circ} 14$

if type $($ dome, mosque $)=$ small $\wedge$ type $($ prayer_hall, mosque $)=$ small $\wedge$ type $($ minaret, mosque $)=$ small

$$
\begin{gathered}
\text { then } \\
\text { type }(\text { mosque })= \\
\text { small }
\end{gathered}
$$

\subsection{Rules Related to Dimensional Relationships in the Prayer Hall}

Among the rules that we specified we find those concerning dimensional relationships in the prayer hall

Rule $n^{\circ} 15$

if $\ell=d=1 / 3 \mathrm{D} \wedge k \leq \mathrm{H} \quad$ then $($ forme $)=$ square

Rule $n^{\circ} 16$

then

if $d=1 / 3 \mathrm{D} \wedge \mathrm{L}=\mathrm{D} \wedge \ell=1 / 3 \mathrm{~L} \wedge k<\mathrm{H} \quad$ form $($ dome $)=$ octogonal

Rule $n^{\circ} 17$

then

if $d=1 / 2 \mathrm{D} \quad$ form $($ dome $)=$ hexagonal

where: $\ell$ : the width of the lateral elements, L: the length of 
the facade elements, $h$ : the height of the additional elements, $d$ : diameter of the corner cupola, $\mathrm{H}$ : height of the lower part of the dome

We were able to specify rules indicating the type of a mosque (small viziral or imperial) from information concerning the central dome (shape, position and diameter), the prayer hall (area, type of additional elements, and type of input device ...), the number of minarets and dimensional relationships of the various components of the prayer hall.

\section{Using Decision Procedures}

Architectural rules are very useful for architects, especially for three-dimensional reconstruction of buildings and for the determination of historical periods, related to the construction of archaeological monuments, with more precision. These rules are defined by the user based on historical documents and therefore can be a source of ambiguity, inconsistency or lack of clarity. That is why we have proposed to use the first-order logic to specify the architectural rules. Then we use the arithmetic decision procedures for testing the consistency of such rules. A set of architectural rules is inconsistent if and only if it expresses contradictions or generates dilemmas. To check the consistency of a set of architectural rules, we need to generate specific consequences of certain formulas of the first order.

In the case of our study, and after the creation of the knowledge base, we used the arithmetic decision procedures on one hand to test the consistency of rules and on the other to minimize the interaction with the user during the modeling of Ottoman mosques. Indeed, during the modeling process of a mosque, the user will need to introduce a limited number of data. The remaining information can be inferred automatically using decision procedures based on the knowledge base [22 and 23].

\subsection{Checking the Consistency of Rules}

By using decision procedures, we can check the consistency of the rule base. We have two rules (the rule $n^{\circ} 7$ and the rule $n^{\circ} 8$ ) with the same premises with different conclusions. This can be a source of ambiguity

Rule $n^{\circ} 7$

if nbre (minarets (a) mosque) $=1$

then

type(minaret, mosque) $=$ Small

Rule $n^{\circ} 8$

if nbre (minaret

s (a) mosque $=1$

then

type(minaret, mosque)

$=$ Viziral
We can use the decision procedures to check the consistency of the parameter values entered by the user in relation to the knowledge base. Consider the example where the user introduces the following data:

form $($ dome, mosque $)=(3)$

position (dome, mosque $)=(d)$

diameter (dome, mosque) $=20$

nbre (minarets, (c), mosque) $=4$

surface (prayer_hall, mosque) $=900 \mathrm{~m}^{2}$

access device (prayer_hall, mosque) $\in\{A\}$

$d=10$

We can deduce that these data correspond to those related to the dome of a mosque in the imperial style (see figure 18). But the value $\mathrm{d}=10$ corresponds to hexagonal dome according to rule $\mathrm{n}^{\circ} 17$ that does not belong to the forms of the imperial style dome.

\subsection{Using Decision Procedures to Minimize User Interaction}

We can use the decision procedures for automation with minimal user interaction. Take the case of a user who inserted: $\mathrm{D}=$ diameter (dome, mosque) $=16$, the system can deduce according to rule $n^{\circ} 1$ that the type of the dome of the mosque is viziral, that the shape of the dome of the mosque belongs to the set (I) and the position of the dome belongs to the set (II) (see Figure 19). By introducing the value $d=$ diameter (dome, area) $=8$, the system can be inferred from the Rule $n^{\circ} 7$ it is hexagonal dome (see (7) (I) of Figure 19).

\section{Conclusion}

We have through this paper presented an ongoing work on the development of a technique for semi-automatic modeling of ottoman mosques that allows to take advantage of architectural knowledge and expertise to support designers in their work of reflection. A first step of this work was to design a database that can be exploited through an interactive interface responding to multiple and targeted queries. It allows us to understand the morphological characteristics of ottoman mosques and the laws that govern them. It can also be used in the context of education to enhance the learning by doing which is a fundamental pedagogical approach in institutional education of architecture.

Aware that the rules are defined by the user on the basis of historical documents can be a source of ambiguity, inconsistency or lack of clarity, we have proposed to use the first-order logic to specify the architectural rules related to these mosques using Horn clauses. Subsequently, we used the decision-making procedures, to check the consistency of the rule base. Implementation is in progress and preliminary results are promising.

\subsection{Using Decision Procedures to Verify the Consistency of Parameter Values Introduced by the User}

\section{REFERENCES}


[1] O. Al Khalil, and P. Grussenmeyer, Single image and topoly approaches for modeling buildings, ISPRS (International Society of Photogrammetry and Remote Sensing), 2002.

[2] N. Yastikli, O. Emem, and Z. Alkis, 3D Model generation and visualization of cultural heritage, XIX CIPA Symposium (The International Committee for Documentation of Cultural Heritage), Antalya, Turkey: ISPRS (International Society of Photogrammetry and Remote Sensing), 2003.

[3] M. Balzani, A. Pellegrinelli, N. Perfetti, and F. Uccelli, A terrestrial 3D laser scanner: Accuracy tests, proceding of XVIII CIPA International Symposium, pp. 445-453, 2001.

[4] C. Alessandri, M.Balzani, N. Zaltron and F. Uccelli, A 3D Laser Scanner model as virtual database, 22nd International Symposium on Automation and Robotics in Construction (ISARC), Ferrara (Italy), pp. 445-453, 2005.

[5] F. Dekeyser, F. Gaspard, L. De Luca, M. Florenzano, X. Chen, and P. Lepray, Architectural drawing of heritage by laser scanning, computer vision and Exploitation of architectural rules, Symposium «Maquette virtuelle et patrimoine», 2003.

[6] T. Yazar and B. Çolakoglu, Computer-Aided Instruction Tools for Architecture: Case study of sinan mosques. YTÜ Arch. Fac. E-Journal. İstanbul, Turkey: MEGARON, 2007.

[7] C. Chevrier and JP. Perrin, 2008, Interactive parametric modelling: POG a tool th cultural heritage monument 3D reconstruction, CAADRIA conference, Chiang Mai, Thailand.

[8] N. Allani-Bouhoula and JP. Perrin, Architectural Rules for Three-Dimensional Reconstruction, Proceedings of the Tenth IASTED International Conference on Computer Graphics and Imaging (CGIM '08), Innsbruck, Austria. Acta Press. ISBN: 978-0-88986-720-8, pp.237-242, 2008.

[9] N. Allani-Bouhoula, Using Arithmetic Decision Procedures to Verify the Consistency of Architectural Rules, Proceedings of the International Conference on Digital Media and its Applications in Cultural Heritage (DMACH '08), Petra University, Amman, Jordan, pp. 143- 159, 2008.

[10] N. Allani-Bouhoula and JP. PERRIN, Architectural Knowledge for Three Dimensional Reconstruction,
International Journal of Design Sciences and Technology, Volume 17, Number 1, ISSN 1630 - 7267, pp 23-38, 2010.

[11] I. H. Güngor, The Dome in Sinan's Work, I. E. Centre, Ed, Environmental Journal of Design, pp. 156-167, 1987.

[12] H. Mnajja, Modeling Ottoman mosques-domed mosques of Sinan in the sixth century, Memory Masters in Architecture supervised by Najla Allani Bouhoula, National School of Architecture and Urbanism, 2009.

[13] N. Allani-Bouhoula, Architectural Knowledge for Modeling in Architecture, Habilitation Degree in Architecture, National School of Architecture and Urbanism, University of Carthage,October 2010.

[14] U. Vogt-Goknil, Grands courants de l'architecture islamiques: mosquées. lausanne, Suisse: Chêne, 1975.

[15] K. Otto-Dorn, L'art de l'islam, Albin Michel, Paris, 1964

[16] T. Burckhardt, L'art de l'Islam, langage et signification, Sindbad, Paris, 1985

[17] L. Golvin, Essai sur l'architecture religieuse musulmane, t. III, Paris, Klincksieck, 1974.

[18] L. Mozzati, L'art de l'Islam, Paris, Mengès, 2003.

[19] H. Stierlin, L'art de l'Islam en méditerranée d'Istanbul à Cordoue, Paris, Gründ, 2005.

[20] B. Duprat, Morphologie appliquée: l'analyse des conformations architecturales, ses problèmes, ses principes, ses méthodes, HDR, Lyon III: Université jean moulin, Faculté de philosophie, 1999.

[21] S. Yerasimos, Sinan and his patrons: programme and location, I. e. center, Ed, Environmental Design: Journal of the islamic environmental design research, pp.124-131, 1987.

[22] R. Shostak, A practical decision procedure for arithmetic with function symbols. JACM, 26(2) , 351-360.

[23] S. Mclaughlin \& J. Harrison, A Proof-Producing Decision Procedure for Real Arithmetic. Proceedinds of CADE-20: 20th International Conference on Automated Deduction. Tallinn Estonia: Springer-Verlag, Lecture Notes in Com, 2005. 